\title{
Characterization of novel natural fiber from manau rattan (Calamus manan) as a potential reinforcement for polymer-based composites
}

\section{Linhu Ding}

Nanjing Forestry University

Xiaoshuai Han ( $\sim$ hxs141424@163.com )

Nanjing Forestry University

Huiling Li

Nanjing Forestry University

Jingquan Han

Nanjing Forestry University

\section{Lihua Cao}

Nanjing Forestry University

\section{Yiming Chen}

Nanjing Forestry University

Zhe Ling

Nanjing Forestry University

Shuijian He

Nanjing Forestry University

Shaohua Jiang

Nanjing Forestry University

\section{Research Article}

Keywords: Manau rattan (Calamus manan), Natural fiber, Reinforcement, Composite

Posted Date: May 10th, 2021

DOl: https://doi.org/10.21203/rs.3.rs-463693/v1

License: (c) (i) This work is licensed under a Creative Commons Attribution 4.0 International License.

Read Full License 


\section{Characterization of novel natural fiber from manau rattan (Calamus}

manan) as a potential reinforcement for polymer-based composites

3 Linhu Ding ${ }^{\mathrm{a}}$, Xiaoshuai Han ${ }^{\mathrm{a} *}$, Huiling $\mathrm{Li}^{\mathrm{a}}$, Jingquan Han ${ }^{\mathrm{a}}$, Lihua Cao ${ }^{\mathrm{a}}$, Yiming Chen ${ }^{\mathrm{a}}$,

4 Zhe Ling ${ }^{\mathrm{b}}$, Shuijian $\mathrm{He}^{\mathrm{a}}$, Shaohua Jianga*

5 a Jiangsu Co-Innovation Center of Efficient Processing and Utilization of Forest 6 Resources, International Innovation Center for Forest Chemicals and Materials, 7 College of Materials Science and Engineering, Nanjing Forestry University, Nanjing, 8 210037, China.

$9{ }^{b}$ Jiangsu Co-Innovation Center of Efficient Processing and Utilization of Forest 10 Resources, College of Chemical Engineering, Nanjing Forestry University, Nanjing 11 210037, China.

12 Email: 2215617702@qq.com (L. Ding), 1932651941@qq.com (H. Li), hjq@njfu.edu.cn (J. Han), 13 541004274@qq.com (L. Cao),747883685@qq.com (Y. Chen), jiling19@njfu.edu.cn (Z. Ling), 14 shuijianhe@njfu.edu.cn (S. He)

$15 *$ hxs141424@163.com (X. Han)

16 *shaohua.jiang@njfu.edu.cn (S. Jiang)

\section{Abstract}

The study on novel natural fibers in polymer-based composites will help promote the invention of novel reinforcement and expand their possible applications. Herein, novel cellulosic fibers were extracted from the stem of manau rattan (Calamus manan) by mechanical separation. It is the first time to comprehensively analyze and study the chemical, thermal, mechanical and morphological properties of manau rattan fibers by Fourier Transform Infrared Spectroscopy (FTIR), X-Ray Photoelectron Spectroscopy (XPS), X-Ray Diffraction Analysis (XRD), Thermogravimetric Analysis (TGA), single fiber tensile test and Scanning Electron Microscopy (SEM). Component analysis results showed the cellulose, hemicellulose and lignin contents of manau rattan fibers were 42,20 , and $27 \%$, respectively. The surface of the rattan fiber was hydrophilic according to the oxygen/carbon ratio of 0.49 . Manau rattan has a high crystalline index of $48.28 \%$, inducing a high maximum degradation temperature of $332.8^{\circ} \mathrm{C}$. This reveals that it can be used as a reinforcement for thermoplastic composites whose operating temperature is below $300^{\circ} \mathrm{C}$. The average tensile strength can reach $273.28 \mathrm{MPa}$, which is beneficial to 30 improve the mechanical properties of rattan fiber reinforced composites. SEM images displayed the 31 rough surface of the fiber, which helps to enhance the interfacial adhesion between the fibers and matrices 32 in composites. This work was also in comparison with some other natural fibers. The above analysis and 
33 research showed the great potential of manau rattan fibers as the reinforcement in polymer-based 34 composites.

35 Keywords: Manau rattan (Calamus manan), Natural fiber, Reinforcement, Composite

\section{Acknowledgement}

37 The study was funded by the National Natural Science Foundation of China (No. 51803093) and Natural

38 Science Foundation of Jiangsu Province (No. BK20180770).

\section{Introduction}

40 Nowadays, with the development of modern civilization, environmental problems, depletion of oil

41 resources and global waste issues are becoming more and more serious. Natural fibers have attracted

42 increased research interest of many researchers due to their environmental friendliness, abundant reserves,

43 renewability, biodegradability, light weight, high strength, etc. (Porras et al. 2015). Synthetic fibers

44 commonly used today like glass fiber, aramid, carbon fiber, etc. are costly, not biodegradable and harmful

45 to human in long-term exposure (Dris et al. 2018). Therefore, the development of new natural fibers or

46 the search for new high-strength natural fibers to replace synthetic fibers are expected to solve the above

47 problems. Natural fiber reinforced composites have gained greater demand in the manufacturing industry,

48 especially in the automotive industry. Now composites made of abaca, flax and hemp fibers with

49 thermoplastic matrices gradually replace the applications of glass fibers in door liners, seat backs,

50 headrests, engine shields, etc. These composites contribute to the lightweight of the car and can reduce

51 skin irritation caused by the use of synthetic materials (Akil and Zamri 2014). Under these circumstances,

52 it is significant to make use of novel materials that contain natural ingredients, such as cellulosic natural

53 fibers. Today, natural fiber reinforced composites have been applied in various areas like sports

54 equipment, construction materials, aircraft parts, naval applications, household appliances and auto parts

55 (Senthamaraikannan and Kathiresan 2018). The prevalent applications encouraged boffins to study novel 
natural cellulosic fibers.

Numerous boffins have characterized natural fibers as reinforcement of composites like cornstalks (Reddy and Yang 2005), Date Palm Fibers (Al-Khanbashi et al. 2005), sisal (Silva et al. 2008), mulberry (Li et al. 2009), okra (Abelmoschus esculentus) (De Rosa et al. 2010), Luffa cylindrica (Seki et al. 2012). Recently, on account of the increasing demand for plant fibers in industry, researchers have sought and studied new natural fibers such as Heteropogon Contortus (Hyness et al. 2017), Conium maculatum (K1lınç et al. 2018), Catharanthus roseus (Vinod et al. 2019), Thespesia populnea (Kathirselvam et al. 2019b), Chrysanthemum morifolium (Dalmis et al. 2020), Hierochloe Odarata (Dalmis et al. 2019).

64 Furthermore, numerous physical or chemical treatments have been applied to make these fibers have better performance and can be used as reinforcement in composites. In this trend, a novel natural fiber originating from the stem of manau rattan (Calamus manan) was extracted and its properties were studied

67 comprehensively for the first time. Manau rattan is a tropical climbing palm (subfamily Calamiodeae of the family Arecaceae) with no branches or seasonal rings (Zampieri et al. 2005). It is native to Sumatra and Indonesia, with an average diameter around $4 \mathrm{~cm}$ while its metaxylem micro-vessels can reach several meters in length. As is known to all, it is one of the most commercially valuable and commonly

71 used rattan palms in the furniture manufacturing industry. There are currently very few characterizations of manau rattan (Calamus manan). Rizkiansyah et al. (2016) extracted microcrystalline cellulose from manau rattan (Calamus manan) through alkalization and acid hydrolysis and investigated the influence

74 of concentration of sulfuric acid and hydrolysis time on crystallinity and thermal resistance of it.

75 Our research is more practical than previous research and can further promote the understanding of rattan, especially its potential of reinforcement in polymer-based thermoplastic composites. This could 77 potentially help the development and research of new materials used in industry, especially the 
automotive and aerospace industries. Herein, mechanical separation was utilized to extract fibers from the rattan stem. For the purpose of determining its feasibility as a reinforcing phase in composites, manau rattan fibers were characterized by chemical composition analysis, Fourier Transform Infrared

81 Spectroscopy (FTIR), X-Ray Photoelectron Spectroscopy (XPS), X-Ray Diffraction Analysis (XRD),

82 Thermogravimetric Analysis (TGA), single fiber tensile test and Scanning Electron Microscopy (SEM).

\section{Materials and methods}

\section{Materials}

85 Manau rattan (Calamus manan) was harvested from Indonesia with an air-dry density of about $0.45 \mathrm{~g} / \mathrm{cm}^{3}$.

86 Its stem is cylindrical with diameter of about $40 \mathrm{~mm}$ (Fig. 1).

\section{Methods}

\section{Fiber extraction}

89 The stem of manau rattan was cut into $250 \mathrm{~mm}$ length approximately followed by decortication, and then soaked in deionized water and washed to remove dust and impurities. It was dried at $60{ }^{\circ} \mathrm{C}$ for 3 days to

91 get rid of water. It was split into thin plates by using a knife and cut into thin strips via scissors. Later it was torn apart by hand. At this time, the preliminarily obtained rattan fibers were passed through the

93 screen and drawn out from the mesh opening. In this experiment, a 100-mesh screen was used, and the corresponding aperture was $0.15 \mathrm{~mm}$. Manau rattan fibers were sanded with fine sandpaper to remove burrs. Finally, the fibers were washed with deionized water and oven-dried at $60{ }^{\circ} \mathrm{C}$ overnight. In this way, manau rattan fibers were obtained (Fig. 1). 


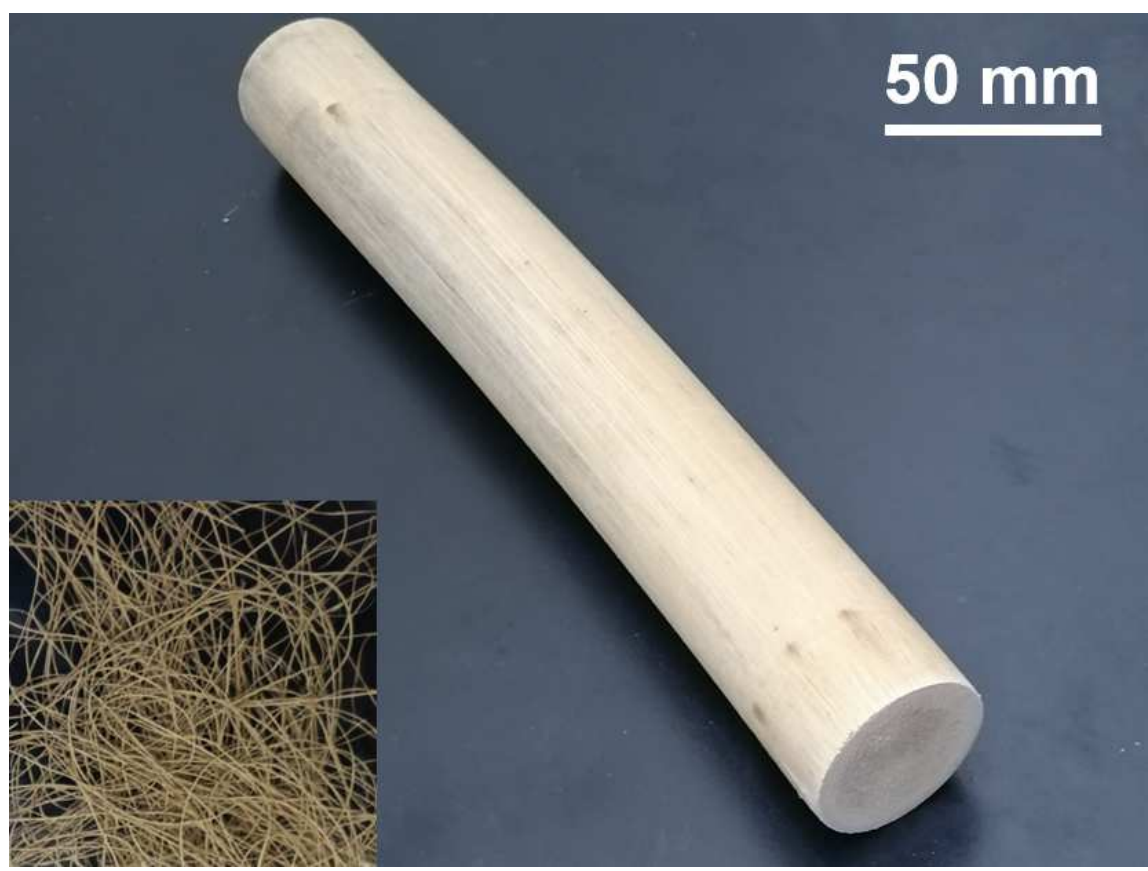

Fig. 1 Stem of manau rattan with its extracted fiber

\section{Chemical composition}

100 The rattan fibers were ground into powder followed by drying in a oven at $105^{\circ} \mathrm{C}$ for 4 hours to get rid

101 of water. It was put in a drying apparatus at last. Cellulose content of manau rattan fiber was measured

102 in accordance with Kurshner and Hoffer's method, while hemicellulose content was evaluated as per the

103 NFT 12-008 standard. The lignin content of manau rattan (Klason lignin) was obtained according to the

104 standard TAPPI T 222 om-2 method.

105 Fourier Transform Infrared Spectroscopy (FTIR)

106 The Fourier transform infrared spectroscopy technique was utilized to recognize the chemical functional

107 groups of the rattan fiber. A certain amount of fiber samples were powdered, then mixed with $\mathrm{KBr}$, and

108 pellets were prepared by a press. A FTIR spectrometer (VERTEX 80v, Bruker, Germany) was used to

109 record the FTIR spectrum in the wavenumber range between 500 and $4000 \mathrm{~cm}^{-1}$.

\section{X-Ray Photoelectron Spectroscopy (XPS)}

111 Surface chemistries of manau rattan fibers were studied through XPS analysis. The spectra were obtained 
112 through X-ray photoelectron spectroscopy (AXIS Ultra, USA), equipped with a monochromatic Al-Ka

$113(1486.7 \mathrm{eV})$ radiation source and a beam diameter of $400 \mathrm{~nm}$. Spectra data was acquired with the vacuum

114 pressure lower than $10^{-9}$ Torr. X-ray source was used in the region between 1350 and 10 eV. Pass energy

115 and energy step size were determined as $150 \mathrm{eV}$ and $1 \mathrm{eV}$, respectively.

116 X-Ray Diffraction (XRD)

117 X-ray diffraction was conducted on the device of an X-ray diffraction analyzer (Ultima IV, Rigaku, Japan)

118 with $\mathrm{Cu}-\mathrm{K} \alpha$ radiation $\left(\lambda-\mathrm{K} \alpha_{1}=1.54 \AA\right)$ at room temperature. At $40 \mathrm{kV}$ and $30 \mathrm{~mA}$, the spectrum was

119 recorded in steps of $0.02^{\circ}$ between $5^{\circ}$ and $90^{\circ}(2 \theta$ angular ranges). The crystallinity index $(C I)$ of manau

120 rattan fibers was obtained by the subsequent expression (Segal et al. 1959):

$$
C I=\frac{\left(I_{200}-I_{a m}\right)}{I_{200}} \times 100
$$

122 where $I_{200}$ refers to the crystalline peak corresponding to the intensity between $22^{\circ}$ and $23^{\circ}$, while $I_{a m}$

123 is the amorphous fraction corresponding to the intensity of about $18^{\circ}$ lying between the highest two peaks.

124 The crystallite size $(L)$ of manau rattan was computed via the Scherrer's expression (Indran and Raj 125 2015):

$$
L=\frac{K \lambda}{\beta \cos \theta}
$$

127 where $K$ is the Sherrer's constant of $0.89, \lambda$ is the wavelength of the radiation, $\beta$ is the peak's full-width

128 at half-maximum (FWHM) in radians and $\theta$ is the corresponding Bragg angle.

129 Thermogravimetric Analysis (TGA)

130 Thermo gravimetric analysis is a method of measuring the relationship between the mass of the sample

131 and temperature or time under the control of the programmed temperature. Approximately $3.1 \mathrm{mg}$

132 samples were studied through a thermal analyzer (STA 449F3, NETZSCH, Germany). The sample was

133 gradually heated from $30^{\circ} \mathrm{C}$ to $800^{\circ} \mathrm{C}$ with the heating rate of $10^{\circ} \mathrm{C} / \mathrm{min}$. Nitrogen atmosphere remained 
was computed to understand the kinetic parameters of rattan fiber by the Broido's equation (Broido 1969):

$$
\ln \left[\ln \left(\frac{1}{y}\right)\right]=-\left(\frac{E}{R}\right)\left[\left(\frac{1}{T}\right)+K\right]
$$

137 where $y$ is the normalized weight $\left(w_{t} / w_{0}\right), w_{t}$ is the weight of the sample at any time $t$ and $w_{0}$ represents

138 the initial weight of the sample, $R$ signified the universal gas constant $(8.314 \mathrm{~J} / \mathrm{mol} \mathrm{K}), T$ symbolizes the

139 temperature in Kelvin, and $K$ is constant.

\section{Single fiber tensile test}

141 The tensile test was performed on 3365 universal testing machine (Instron Test Equipment Trading Co.,

142 Ltd., China) at room temperature $\left(25^{\circ} \mathrm{C}\right)$ with the relative humidity of about $65 \% .20$ samples were used

143 in this experiment and they were all dried at $60^{\circ} \mathrm{C}$ for 6 hours before testing. The sizes of all samples

144 were determined via a vernier caliper $( \pm 0.01 \mathrm{~mm})$. The load cell was $1 \mathrm{kN}$ and the crosshead speed was

$1452 \mathrm{~mm} / \mathrm{min}$ with the gauge length of $10 \mathrm{~mm}$. The tensile strength, Young's modulus and elongation at

146 break of manau rattan fibers were obtained from this test. The microfibril angle $(\alpha)$ represents the angle

147 between the microfibril and the fiber axis, which was evaluated from the next formula (Hyness et al.

148 2017):

$$
\varepsilon=\ln \left(1+\frac{\Delta L}{L_{0}}\right)=-\ln (\cos \alpha)
$$

150 Where $\varepsilon$ is the strain, $\alpha$ is the microfibril angle $\left({ }^{\circ}\right), L_{0}$ is the gauge length (mm), and $\Delta L$ is the elongation

151 at break (mm).

\section{Scanning Electron Microscopy (SEM)}

153 Manau rattan fiber's morphologies were observed by a scanning electron microscope (PhenomScientific

$154 \mathrm{XL} \mathrm{G2,} \mathrm{China)} \mathrm{at} \mathrm{an} \mathrm{accelerating} \mathrm{voltage} \mathrm{of} 5 \mathrm{kV}$. Before scanning, gold was plated on the fiber surface

155 by sputtering coating to prevent the electron beam charging effect in the observation process. The surface 
156 morphologies of manau rattan fibers were observed under different magnifications.

\section{Results and discussion}

\section{Chemical composition analysis}

159 The chemical content of manau rattan fiber seriously affects its mechanical properties, flame retardancy,

160 biodegradability, etc. Lignocellulose fibers are mainly composed by cellulose, hemicellulose and lignin

161 (Han et al. 2021). Table 1 lists the chemical composition of manau rattan fiber and some other

162 lignocellulosic fibers for comparison. The cellulose content of manau rattan fiber is $42 \%$, which is higher

163 than Curcuma longa L. (Ilangovan et al. 2018) and comparable to Arundo Donax L. (Fiore et al. 2014),

164 but is lower than Linden (Seki et al. 2014), Thespesia populnea (Kathirselvam et al. 2019b), Ferula

165 communis (Seki et al. 2013), etc. The hydrogen bonds among the cellulose chains can augment

166 crystallinity thereby improving the mechanical properties of manau rattan fiber. Therefore, a higher

167 cellulose content can increase the stiffness of the fiber, which is beneficial to the reinforcement of the

168 composite material. The content of hemicellulose in rattan fiber is $20 \%$, which is equivalent to some

169 other natural fibers, such as Hydrangea macrophylla (Cárdenas-R et al. 2018), Date Palm (Al-Khanbashi

170 et al. 2005) and Arundo Donax L. (Fiore et al. 2014). Higher content of hemicellulose can cause

171 disintegration of cellulose microfibrils, thereby reducing mechanical properties. Compared with other

172 lignocellulosic fibers, the lignin content of rattan fibers is relatively high, which is $27 \%$. Higher content

173 of lignin is conducive to resist the attack from biology. The other chemical components in the fiber are

174 wax, pectin, oil, ash, etc.

175 Table 1 Chemical composition of manau rattan and some other lignocellulosic fibers

\begin{tabular}{ccccc}
\hline Fiber & Cellulose (\%) & Hemicellulose (\%) & Lignin (\%) & References \\
\hline Manau rattan & $\mathbf{4 2}$ & $\mathbf{2 0}$ & $\mathbf{2 7}$ & This work \\
Mulberry barks & 37 & 25 & 10 & (Li et al. 2009)
\end{tabular}




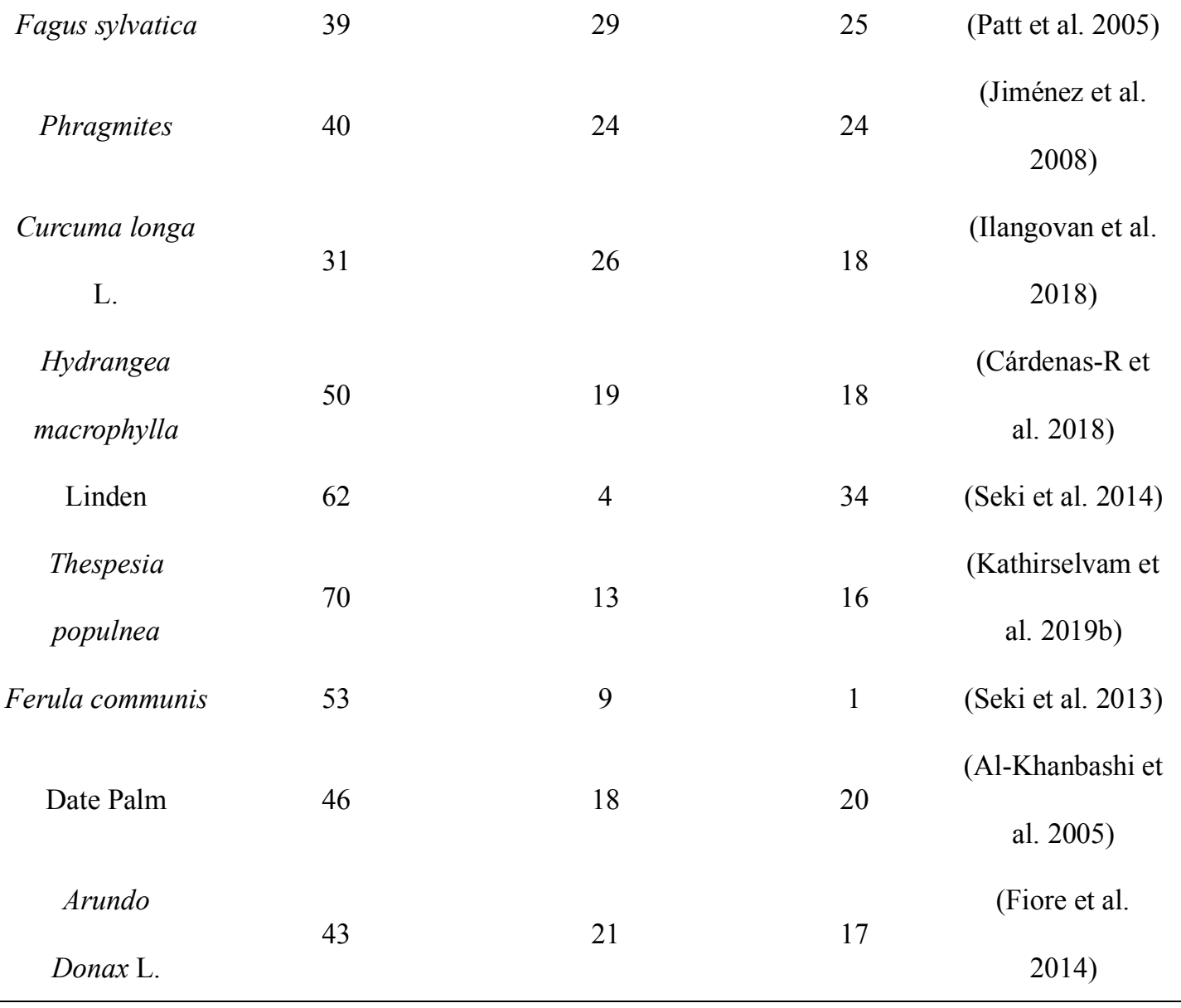

\section{FTIR analysis}

177 The FT-IR spectrum of rattan fiber is shown in Fig. 2. The peak observed at $3429 \mathrm{~cm}^{-1}$ is connected with

178 the characteristic of $\mathrm{O}-\mathrm{H}$ stretching vibration and hydrogen bond of the hydroxyl groups (Manimaran et

179 al. 2018). The peak at $2923 \mathrm{~cm}^{-1}$ is in connection with $\mathrm{C}-\mathrm{H}$ stretching vibration from $\mathrm{CH}$ and $\mathrm{CH}_{2}$ in

180 cellulose and hemicellulose (Indran and Raj 2015). The peak at $1740 \mathrm{~cm}^{-1}$ is associated with stretching

181 vibration of the $\mathrm{C}=\mathrm{O}$ group in the ester group of hemicellulose or carboxylic acid in lignin (De Rosa et

182 al. 2010). The wavenumber around $1629 \mathrm{~cm}^{-1}$ belongs to the carbonyl groups $(\mathrm{C}=\mathrm{O})$ of lignin and

183 hemicellulose (Belouadah et al. 2015). The peak at $1506 \mathrm{~cm}^{-1}$ indicates $\mathrm{C}=\mathrm{C}$ stretching of aromatic lignin

184 (Seki et al. 2014). The presence of peak around $1426 \mathrm{~cm}^{-1}$ is related to the symmetric bending of $\mathrm{CH}_{2}$ in

185 cellulose (Manimaran et al. 2018). A peak detected at $1376 \mathrm{~cm}^{-1}$ is attributed to C-H groups of cellulose

186 (Belouadah et al. 2015). Vibration peak of $1246 \mathrm{~cm}^{-1}$ means C-O stretching vibration of the acetyl groups 
193

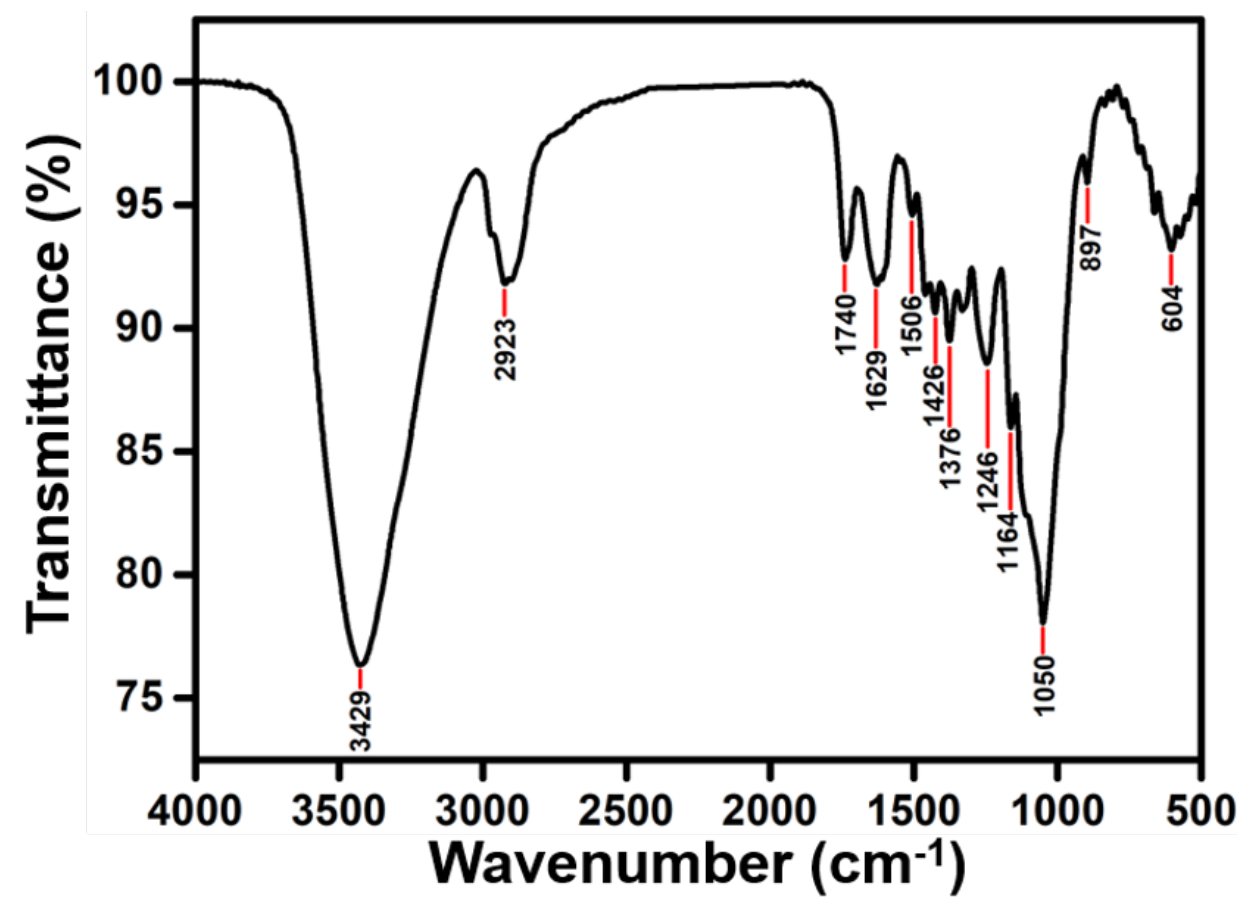

Fig. 2 FTIR spectra of manau rattan fibers

\section{XPS analysis}

The atomic concentrations and $\mathrm{O} / \mathrm{C}$ ratios for rattan fiber is given in Table 2. The relative surface composition of rattan fiber is $63.44 \% \mathrm{C}, 31.08 \% \mathrm{O}, 1.64 \% \mathrm{~N}$ and $3.85 \% \mathrm{Si} . \mathrm{O} / \mathrm{C}$ ratio of rattan fiber is obtained as 0.49 , which is higher than many other mostly utilized lignocellulosic fibers such as Linden (0.13) (Seki et al. 2014), Conium maculatum (0.21) (Kılınç et al. 2018), Henequen (0.25) (Sgriccia et al. 2008), hemp (0.27) (Sgriccia et al. 2008), Chrysanthemum morifolium (0.41) (Dalmis et al. 2020), Kenaf (0.45) (Sgriccia et al. 2008) and Hierochloe Odarata (0.48) (Dalmis et al. 2019). However, the value is 
202 lower than that of Luffa cylindrica (0.61) (Seki et al. 2013) and oil palm mesocarp fiber (1.00). Generally,

203 a high $\mathrm{C} / \mathrm{O}$ ratio is related to the hydrophobic surface properties of the fiber, which is significant for

204 cellulosic fiber-reinforced composites. Compared with common fibers such as jute with a surface $\mathrm{C} / \mathrm{O}$

205 ratio of 2.09, manau rattan fiber has the potential to become a reinforcing material in composites with a

206 comparable $\mathrm{C} / \mathrm{O}$ ratio (2.04).

207 Table 2 Elemental composition of manau rattan fibers

\begin{tabular}{cccccc}
\hline & C1s (\%) & O1s (\%) & N1s (\%) & Si2p(\%) & O/C \\
\hline Manau rattan & 63.44 & 31.08 & 1.64 & 3.85 & 0.49 \\
\hline
\end{tabular}

208 Deconvolution of C1s and O1s peak were conducted to have a knowledge of the amount of functional

209 groups. The curves are shown in Fig. 3 and the peak distributions and concentrations of related functional

210 groups are shown in Table 3. The peaks at $284.33 \mathrm{eV}, 286.16 \mathrm{eV}$ and $287.82 \mathrm{eV}$ can be ascribed to C-

$211 \mathrm{C} / \mathrm{C}-\mathrm{H}$ groups, $\mathrm{C}-\mathrm{OH} / \mathrm{C}-\mathrm{O}-\mathrm{C}$ groups and $\mathrm{C}=\mathrm{O}$ groups respectively with the proportion of $40.52 \%, 49.54 \%$

212 and $9.94 \%$, while the peaks at $531.75 \mathrm{eV}$ and $532.58 \mathrm{eV}$ belongs to $\mathrm{O}=\mathrm{C}$ groups and $\mathrm{O}-\mathrm{C}$ groups with

213 the proportion of $32.31 \%$ and $67.69 \%$ (Seki et al. 2012). The above functional groups also prove the

214 presence of cellulose, hemicellulose and lignin in manau rattan fibers. Carbonyl groups in lignocellulosic

215 fibers are present in hemicellulose and lignin. Such high carbonyl content confirms the high content of

216 hemicellulose and lignin as shown in Table 1.

217 Table 3 The concentrations of the functional groups on the surface of manau rattan fibers

\begin{tabular}{cccccc}
\hline & $\mathrm{C}-\mathrm{C} / \mathrm{C}-\mathrm{H}$ & $\mathrm{C}-\mathrm{OH} / \mathrm{C}-\mathrm{O}-\mathrm{C}$ & $\mathrm{C}=\mathrm{O}$ & $\mathrm{O}=\mathrm{C}$ & $\mathrm{O}-\mathrm{C}$ \\
\hline $\mathrm{C} 1 \mathrm{~s}$ & & & $\mathrm{O} 1 \mathrm{~s}$ & \\
$\mathrm{eV}$ & 284.33 & 286.16 & 287.82 & 531.75 & 532.58 \\
$\%$ & 40.52 & 49.54 & 9.94 & 32.31 & 67.69 \\
\hline
\end{tabular}



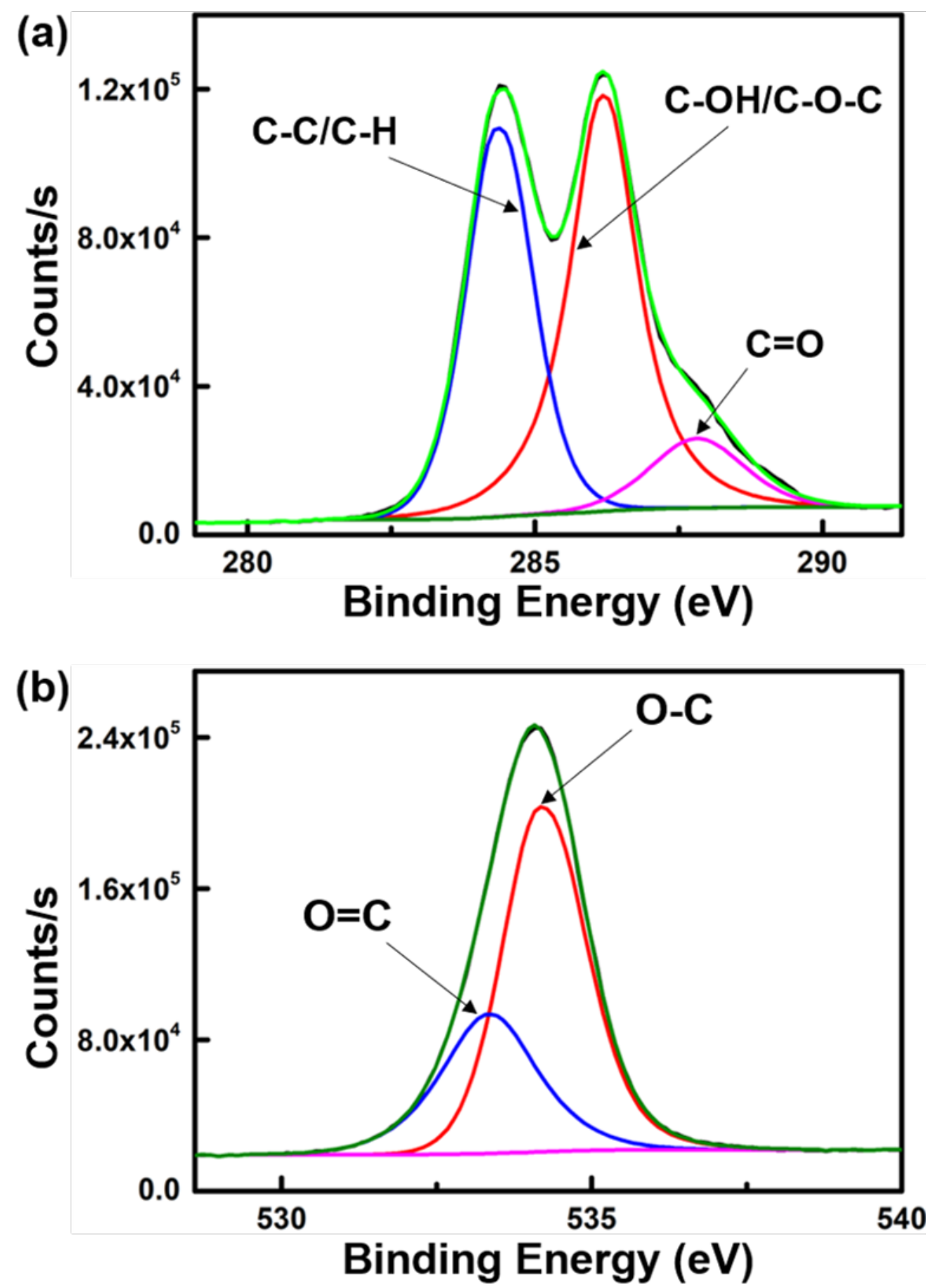

Fig. 3 High resolution XPS spectra showing the deconvoluted C1s (a) and O1s (b) envelope XRD analysis

$221 \mathrm{XRD}$ is a technique that uses $\mathrm{x}$-rays to diffract a sample to analyze its structure. Fig. 4 shows the XRD

222 graph of manau rattan fibers. Two peaks at $16.02^{\circ}$ and $21.94^{\circ}$ by the planes $(1 \pm 10$ and 200$)$ are relevant

223 peaks of cellulose I and IV respectively (Seki et al. 2012). The crystalline peak of (1-10) and (110) at 

corresponds to the amorphous component. The crystallinity index $(\mathrm{CI})$ of manau rattan computed via Eq.

226 (1) is $48.28 \%$, higher than date palm (20\%) (Abdal-hay et al. 2012). However, the $C I$ of manau rattan

227 fibers is less than many other natural fibers like Conium Maculatum (56\%) (Kılınç et al. 2018) and Sansevieria cylindrica (60\%) (Belouadah et al. 2015). The high amount of non-cellulosic materials may account for this. The crystallite size ( $L$ ) of manau rattan fibers calculated from Eq. (2) is $1.91 \mathrm{~nm}$. The $L$ of some other natural fibers are flax fibers $(2.8 \mathrm{~nm})$ (Reddy and Yang 2005) and Funacel $(4.5 \mathrm{~nm})(\mathrm{Kim}$ et al. 2010). It is precisely because of the small crystallite size that the number of amorphous structures

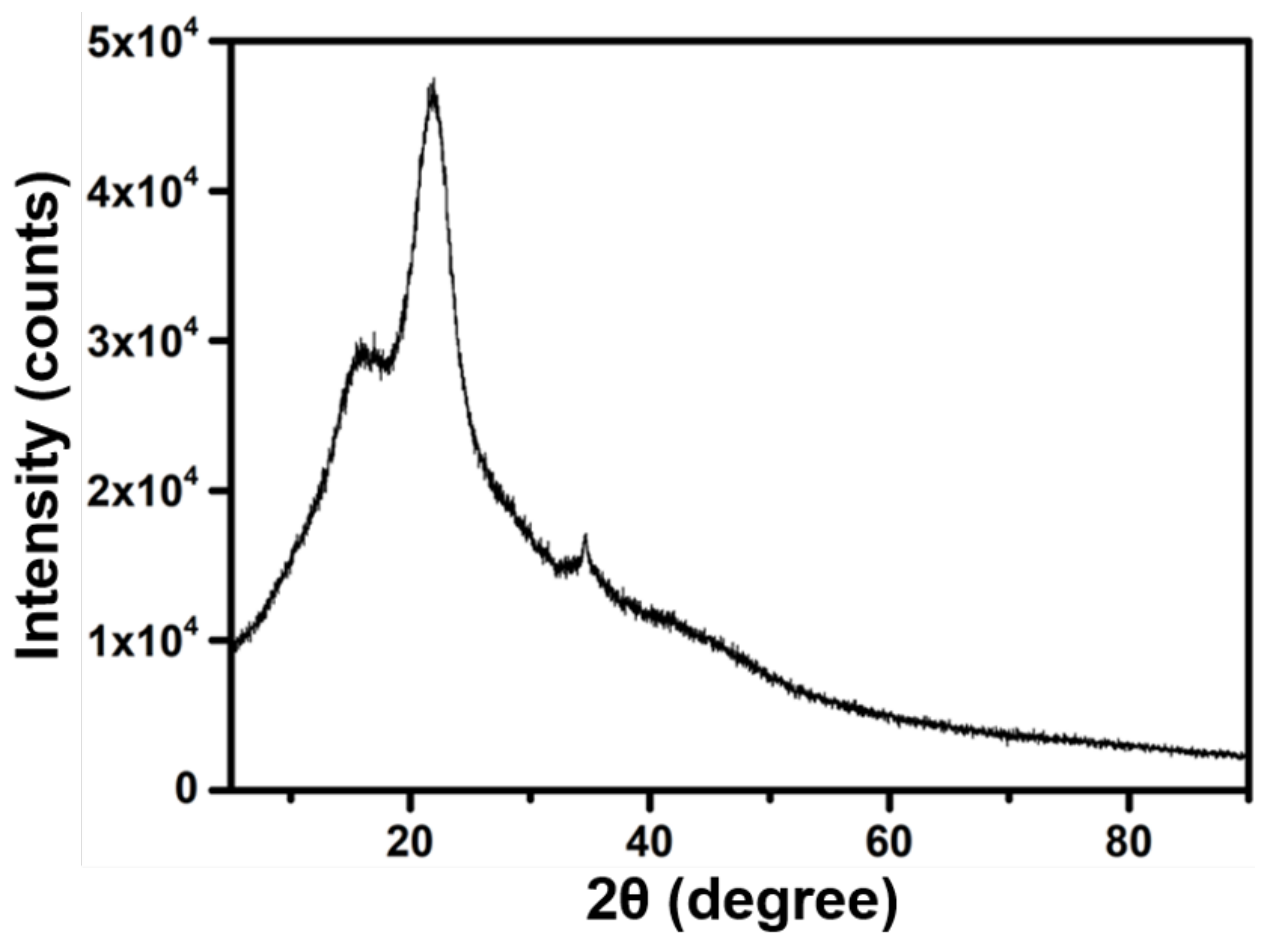

Fig. 4 XRD graph of manau rattan fibers

\section{TGA analysis}

236 Generally, high temperatures are required to manufacture fiber-reinforced thermoplastic composite

237 materials. The thermogravimetric (TG) and its derivative thermogravimetric (DTG) curves for manau 
rattan fibers are given in Fig. 5a. Three main weight loss steps are observed. The initial step (2.29\%) is seen between $50{ }^{\circ} \mathrm{C}$ and $100{ }^{\circ} \mathrm{C}$, which represents the evaporation of moisture (Kılınç et al. 2018). The

240 second weight loss with $13.51 \%$ occurs between $100{ }^{\circ} \mathrm{C}$ and $280{ }^{\circ} \mathrm{C}$, which corresponds to the 241 decomposition of hemicellulose and the glycosidic linkages of cellulose (Indran and Raj 2015). The 242 maximum weight loss of manau rattan fibers is seen between $280^{\circ} \mathrm{C}$ and $360^{\circ} \mathrm{C}$, and it is also the third 243 weight loss stage with a weight loss of $62.24 \%$. It is associated with the decomposition of cellulose I and $244 \alpha$-cellulose (Fiore et al. 2014). Then comes the decomposition of lignin. Finally, 17.35\% of the initial 245 weight is kept at $800{ }^{\circ} \mathrm{C}$. DTG data shows that the maximum degradation rate of rattan fiber occurs at $246332.8^{\circ} \mathrm{C}$. Similar peak related to the decomposition of cellulose were reported for various fibers such as 247 Lygeum spartum $\left(338.7^{\circ} \mathrm{C}\right)$, Cissus quadrangularis root $\left(328.9^{\circ} \mathrm{C}\right)$, Chloris Barbata $\left(324.6{ }^{\circ} \mathrm{C}\right)$ and 248 Thespesia populnea $\left(323.8^{\circ} \mathrm{C}\right)$ (Belouadah et al. 2015; Indran and Raj 2015; Kathirselvam et al. 2019b).

249 The kinetic activation energy $(E)$ calculateded from the Broidio's plot (Fig. $5 b)$ of $(\ln [\ln (1 / y)])$ verses

$250(1 / \mathrm{T})$ is $81.68 \mathrm{~kJ} / \mathrm{mol}$. The kinetic activation energy of rattan fiber is in the range of $60-170 \mathrm{~kJ} / \mathrm{mol}$ which 251 specifies the activation energy margin of woods decomposition, indicating that rattan fiber has heat 252 resistance when preparing fiber-reinforced polymer composites and can withstand the temperature during 253 the polymerization process (Saravanakumar et al. 2013). The kinetic activation energy (E) of manau 254 rattan fiber is higher than Lygeum spartum $(68.77 \mathrm{~kJ} / \mathrm{mol})$, Furcraea foetida $(65.64 \mathrm{~kJ} / \mathrm{mol})$ and close to 255 Prosopis juliflora (76.72 kJ/mol), Cissus quadrangularis root (74.18 kJ/mol) (Belouadah et al. 2015; 256 Indran and Raj 2015; Manimaran et al. 2018; Saravanakumar et al. 2013). As shown in Fig. 5a, manau 257 rattan fibers are thermally stable up to $220^{\circ} \mathrm{C}$. The above results confirm that rattan fiber is suitable to 258 be a reinforcement in composites, especially in polymer-based composites owing to its relatively high 259 onset temperature. 


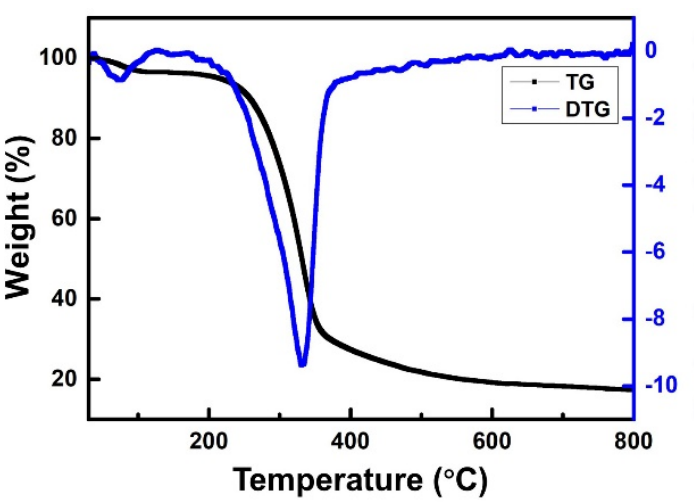

260

\section{Single fiber tensile properties}

263 Fig. 6a shows three representative stress-strain curves of rattan fiber. It can be seen that when fiber failure occurs, it exhibits brittle behavior (De Rosa et al. 2010). Rattan fibers exhibit an initial linear deformation delamination between fiber cells and the collapse of the weaker primary cell wall (Belouadah et al. 2015).

Fig. $6 \mathrm{~b}$ displays the mechanical properties of manau rattan fibers. The tensile strength, Young's modulus and elongation at break of manau rattan fibers with some other natural fibers are shown in Table 4. The tensile strength of rattan fiber is $273.28 \pm 52.88 \mathrm{MPa}$, higher than Catharanthus roseus (Vinod et al.

271 2019) and lower than Ferula communis (Seki et al. 2013). Young's modulus is $7.80 \pm 1.70$ GPa while 272 the elongation at break is $9.40 \pm 3.67 \%$. The deviation value of tensile properties of rattan fiber are

273 slightly high. This is caused by the following factors: the position of the fiber in the plant (K1lınç et al.

274 2018), the presence of defects (Silva et al. 2008), the hypothesis of circular cross-section of fiber (Fiore 275 et al. 2014).

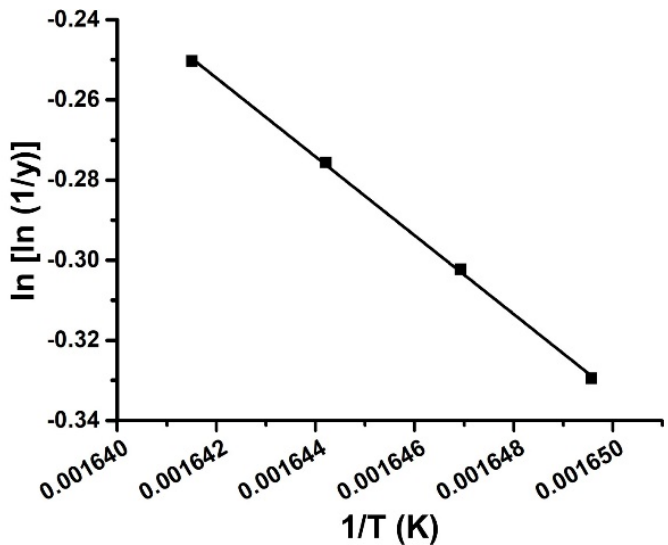

(a) and Broido's plot of manau rattan fibers (b) 

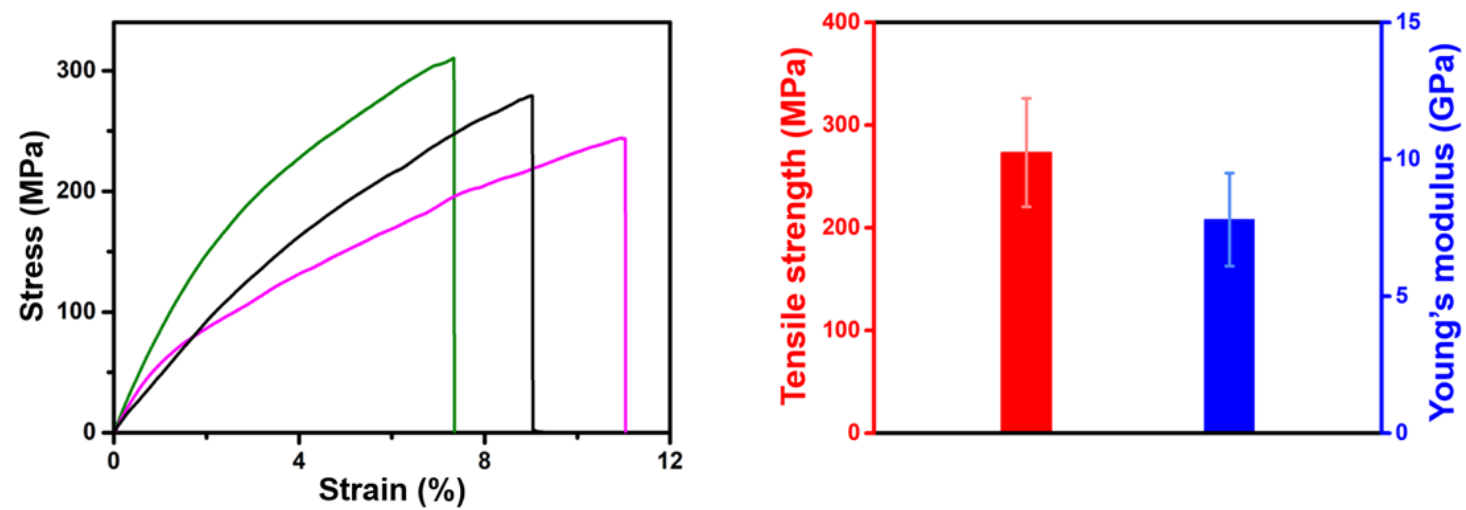

Fig. 6 (a) Tensile stress-strain curve of manau rattan fiber and (b) its corresponding mechanical

properties

279 Table 4 Mechanical properties of manau rattan fibers as compared with some cellulosic fibers

\begin{tabular}{|c|c|c|c|c|}
\hline Fiber & $\begin{array}{l}\text { Tensile strength } \\
\qquad(\mathrm{MPa})\end{array}$ & $\begin{array}{c}\text { Young's } \\
\text { modulus (GPa) }\end{array}$ & $\begin{array}{l}\text { Elongation at } \\
\text { break (\%) }\end{array}$ & References \\
\hline Manau rattan & $273.28 \pm 52.88$ & $7.80 \pm 1.70$ & $9.40 \pm 3.67$ & This work \\
\hline Sisal & 274 & 7 & 2 & (Silva et al. 2008) \\
\hline $\begin{array}{c}\text { Areca palm leaf } \\
\text { stalk }\end{array}$ & 365 & 9 & 3 & $\begin{array}{c}\text { (Shanmugasundaram } \\
\text { et al. 2018) }\end{array}$ \\
\hline Ferula communis & 476 & 53 & 4 & (Seki et al. 2013) \\
\hline $\begin{array}{l}\text { Catharanthus } \\
\text { roseus }\end{array}$ & 27 & 1 & 2 & (Vinod et al. 2019) \\
\hline Elephant Grass & 292 & 10 & 3 & $\begin{array}{c}\text { (Belouadah et al. } \\
\text { 2015) }\end{array}$ \\
\hline Date Palm & 170 & 5 & 10 & $\begin{array}{c}\text { (Al-Khanbashi et al. } \\
\text { 2005) }\end{array}$ \\
\hline Arundo Donax & 248 & 9 & 3 & (Fiore et al. 2014) \\
\hline $\begin{array}{c}\text { Juncus effusus } \\
\text { L. }\end{array}$ & 113 & 4 & 3 & (Dalmis et al. 2019) \\
\hline Oil palm & 248 & 3 & 25 & $\begin{array}{c}\text { (Indran and Raj } \\
\text { 2015) }\end{array}$ \\
\hline $\begin{array}{l}\text { Sansevieria } \\
\text { cylindrica }\end{array}$ & 658 & 7 & 12 & $\begin{array}{l}\text { (Indran and Raj } \\
\text { 2015) }\end{array}$ \\
\hline
\end{tabular}


280 The microfibril angle $(\alpha)$ of rattan fiber calculated from Eq. (4) is $23.47 \pm 3.97^{\circ}$. The value is lower than 281 that found in Coir $\left(30.45^{\circ}\right)$ (Sathishkumar et al. 2013) and Rhectophyllum camerunense $\left(40.1 \pm 0.5^{\circ}\right)$

282 (Béakou et al. 2008) while higher than Thespesia populnea $\left(13.94 \pm 1.21^{\circ}\right)$ (Kathirselvam et al. 2019a)

283 and Heteropogon contortus $\left(14.53 \pm 0.53^{\circ}\right.$ ) (Hyness et al. 2017). Large microfibril angle indicates an

284 important strain value, which is associated with the reorientation of the microfibrils along the fiber axis

285 in the tensile test. The smaller angle contributes to higher strength and stiffness, while a larger angle can

286 provide higher ductility. The microfibril angle of rattan fiber is at a medium level, giving it great strength

287 together with good toughness. In addition, the composition of the fiber also has a great influence on its

288 mechanical properties. High cellulose content can increase tensile strength and Young's modulus for the

289 reason that cellulose has specific characteristics like high degree of polymerization and linear orientation.

290 Relatively high cellulose content (42\%) makes the rattan fibers have good mechanical properties. Fibers

291 rich in cellulose and small microfibril angles are considered to be important features of composite

292 reinforcement. Therefore, manau rattan fiber has great potential to become a reinforcement for green

293 composite materials in the future.

\section{SEM analysis}

295 The surface morphology of a fiber significantly affects its capacity of reinforcement in polymer-based

296 composites. It can be clearly seen from longitudinal image of rattan fiber in Fig. 7a and its enlarged graph

297 Fig. 7b that fine grains are on the rough surface of manau rattan fiber, which may be wax or lignin.

298 Further, these particles increase the surface roughness of the fiber. The surface roughness of the fiber

299 improves the interface adhesion between the fiber and the matrix in polymer-based composites

300 (Alavudeen et al. 2015). Fig. 7c with its enlarged graph Fig. 7d shows the fracture surface picture of

301 rattan fiber after tensile test which reveals that rattan fiber consists of several elementary fibers with a 
brittle fracture behavior of the fibers discussed above.

\section{Conclusion}

310 The research shows the extraction and characterization of novel natural fibers from the stem of manau

311 rattan (Calamus manan) to evaluate their potential to become a reinforcement in composites. Main

312 components of manau rattan fiber like cellulose, hemicellulose and lignin were decided through FTIR

313 along with XRD. Chemical analysis revealed cellulose, hemicellulose and lignin content of manau rattan

314 fiber were $42 \%, 20 \%$, and $27 \%$, respectively. Surface C/O ratio was 2.04 comparable to commonly used

315 fiber like jute (2.09). Manau rattan fiber presents $48.28 \%$ crystallinity index with the crystallite size of

$3161.91 \mathrm{~nm}$. Thermogravimetric analysis manifested that manau rattan fibers are thermally stable up to 

strength, Young's modulus and elongation at break values were $273.28 \pm 52.88 \mathrm{MPa}, 7.80 \pm 1.70 \mathrm{GPa}$, and $9.40 \pm 3.67 \%$, respectively. It was observed by SEM that manau rattan fibers consisted of elementary

321 fibers aligned and bound together by non-cellulose components. The rough fiber surface morphology

322 was observed by SEM, which is conducive to the binding of fiber and polymer matrix in composite 323 materials. In conclusion, manau rattan fibers are good candidate for reinforcement especially in polymer-

324 based thermoplastic composites owing to its high thermal stability, good mechanical properties and rough 325 surface. What's more, surface treatment can be used for increasing the interface adhesion between the 326 hydrophilic natural fibers and the hydrophobic polymer matrices to expand the application of manau 327 rattan fiber as a reinforcement.

\section{Declarations}

\section{Conflict of interest}

330 All authors declare that they have no conflict of interest.

\section{Human and animal rights}

332 The paper does not contain any research on humans or animals by the authors.

\section{References}

334 Abdal-hay A, Putu Gede Suardana, Jung DY, Choi KS, Lim JK (2012) Effect of diameters and alkali 335 treatment on the tensile properties of date palm fiber reinforced epoxy composites. Int J Precis Eng Manuf 336 13(7):1199-1206. https://doi.org/10.1007/s12541-012-0159-3.

337 Akil H, Zamri MH (2014) Natural Fibre Composites. Woodhead Publishing, Cambridge. 338 https://doi.org/10.1533/9780857099228.3.323.

339 Al-Khanbashi A, Al-Kaabi K, Hammami A (2005) Date palm fibers as polymeric matrix reinforcement: 340 Fiber characterization. Polym Compos 26(4):486-497. https://doi.org/10.1002/pc.20118. 
342 properties of banana/kenaf fiber-reinforced hybrid polyester composites: Effect of woven fabric and 343 random orientation. Mater Des 66:246-257. https://doi.org/10.1016/j.matdes.2014.10.067.

344 Béakou A, Ntenga R, Lepetit J, Atéba JA, Ayina LO (2008) Physico-chemical and microstructural 345 characterization of "Rhectophyllum camerunense" plant fiber. Compos Part A Appl Sci Manuf 39(1):67-

346 74. https://doi.org/10.1016/j.compositesa.2007.09.002.

347 Belouadah Z, Ati A, Rokbi M (2015) Characterization of new natural cellulosic fiber from Lygeum 348 spartum L. Carbohydr Polym 134:429-437. https://doi.org/10.1016/j.carbpol.2015.08.024.

349 Broido A (1969) Simple, sensitive graphical method of treating thermogravimetric analysis data. J Polym 350 Sci Pol Phys 7:1761-1773. https://doi.org/10.1002/pol.1969.160071012.

351 Cárdenas-R JP, Cea M, Santín K, Valdés G, Hunter R, Navia R (2018) Characterization and application 352 of a natural polymer obtained from Hydrangea macrophylla as a thermal insulation biomaterial. Compos 353 Part B Eng 132:10-16. https://doi.org/10.1016/j.compositesb.2017.07.086.

354 Dalmis R, Kilic GB, Seki Y, Koktas S, Keskin OY (2020) Characterization of a novel natural cellulosic 355 fiber extracted from the stem of Chrysanthemum morifolium. Cellulose 27(15):8621-8634. 356 https://doi.org/10.1007/s10570-020-03385-2.

357 Dalmis R, Köktaş S, Seki Y, Kılınç AÇ (2019) Characterization of a new natural cellulose based fiber 358 from Hierochloe Odarata. Cellulose 27(1):127-139. https://doi.org/10.1007/s10570-019-02779-1.

359 De Rosa IM, Kenny JM, Puglia D, Santulli C, Sarasini F (2010) Morphological, thermal and mechanical 360 characterization of okra (Abelmoschus esculentus) fibres as potential reinforcement in polymer 361 composites. Compos Sci Technol 70(1):116-122. https://doi.org/10.1016/j.compscitech.2009.09.013.

362 Dris R, Gasperi J, Rocher V, Tassin B (2018) Synthetic and non-synthetic anthropogenic fibers in a river 363 under the impact of Paris Megacity: Sampling methodological aspects and flux estimations. Sci Total 364 Environ 618:157-164. https://doi.org/10.1016/j.scitotenv.2017.11.009.

365 Fiore V, Scalici T, Valenza A (2014) Characterization of a new natural fiber from Arundo donax L. as 366 potential reinforcement of polymer composites. Carbohydr Polym 106:77-83. 367 https://doi.org/10.1016/j.carbpol.2014.02.016.

368 French AD (2013) Idealized powder diffraction patterns for cellulose polymorphs. Cellulose 21(2):885369 896. https://doi.org/10.1007/s10570-013-0030-4.

370 Han XS, Wang ZX, Ding LH, Chen L, Wang F, Pu JW, Jiang SH (2021) Water molecule-induced 
371 hydrogen bonding between cellulose nanofibers toward highly strong and tough materials from wood

372 aerogel. Chin Chem Lett. https://doi.org/10.1016/j.cclet.2021.03.044.

373 Hyness NRJ, Vignesh NJ, Senthamaraikannan P, Saravanakumar SS, Sanjay MR (2017) Characterization

374 of New Natural Cellulosic Fiber from Heteropogon Contortus Plant. J Nat Fibers 15(1):146-153.

375 https://doi.org/10.1080/15440478.2017.1321516.

376 Ilangovan M, Guna V, Hu C, Nagananda GS, Reddy N (2018) Curcuma longa L. plant residue as a source 377 for natural cellulose fibers with antimicrobial activity. Ind Crop Prod 112:556-560. 378 https://doi.org/10.1016/j.indcrop.2017.12.042.

379 Indran S, Raj RE (2015) Characterization of new natural cellulosic fiber from Cissus quadrangularis 380 stem. Carbohydr Polym 117:392-399. https://doi.org/10.1016/j.carbpol.2014.09.072.

381 Jiménez L, Rodríguez A, Pérez A, Moral A, Serrano L (2008) Alternative raw materials and pulping 382 process using clean technologies. Ind Crop Prod 28(1):11-16. 383 https://doi.org/10.1016/j.indcrop.2007.12.005.

384 Kathirselvam M, Kumaravel A, Arthanarieswaran VP, Saravanakumar SS (2019a) Characterization of 385 cellulose fibers in Thespesia populnea barks: Influence of alkali treatment. Carbohydr Polym 217:178386 189. https://doi.org/10.1016/j.carbpol.2019.04.063.

387 Kathirselvam M, Kumaravel A, Arthanarieswaran VP, Saravanakumar SS (2019b) Isolation and 388 characterization of cellulose fibers from Thespesia populnea barks: A study on physicochemical and 389 structural properties. Int J Biol Macromol 129:396-406. https://doi.org/10.1016/j.ijbiomac.2019.02.044. 390 Kılınç AÇ, Köktaş S, Seki Y, Atagür M, Dalmış R, Erdoğan ÜH, Göktaş AA, Seydibeyoğlu MÖ (2018) 391 Extraction and investigation of lightweight and porous natural fiber from Conium maculatum as a 392 potential reinforcement for composite materials in transportation. Compos Part B Eng 140:1-8. 393 https://doi.org/10.1016/j.compositesb.2017.11.059.

394 Kim UJ, Eom SH, Wada M (2010) Thermal decomposition of native cellulose: Influence on crystallite 395 size. Polym Degrad Stab 95(5):778-781. https://doi.org/10.1016/j.polymdegradstab.2010.02.009.

396 Li R, Fei J, Cai Y, Li Y, Feng J, Yao J (2009) Cellulose whiskers extracted from mulberry: A novel 397 biomass production. Carbohydr Polym 76(1):94-99. https://doi.org/10.1016/j.carbpol.2008.09.034.

398 Manimaran P, Senthamaraikannan P, Sanjay MR, Marichelvam MK, Jawaid M (2018) Study on 399 characterization of Furcraea foetida new natural fiber as composite reinforcement for lightweight 400 applications. Carbohydr Polym 181:650-658. https://doi.org/10.1016/j.carbpol.2017.11.099. 
401 Patt R, Kordsachia O, Fehr J (2005) European hardwoods versus Eucalyptus globulus as a raw material

402 for pulping. Wood Sci Technol 40(1):39-48. https://doi.org/10.1007/s00226-005-0042-9.

403 Porras A, Maranon A, Ashcroft IA (2015) Characterization of a novel natural cellulose fabric from

404 Manicaria saccifera palm as possible reinforcement of composite materials. Compos Part B Eng 74:66-

405 73. https://doi.org/10.1016/j.compositesb.2014.12.033.

406 Reddy N, Yang Y (2005) Structure and properties of high quality natural cellulose fibers from cornstalks.

407 Polymer 46(15):5494-5500. https://doi.org/10.1016/j.polymer.2005.04.073.

408 Saravanakumar SS, Kumaravel A, Nagarajan T, Sudhakar P, Baskaran R (2013) Characterization of a 409 novel natural cellulosic fiber from Prosopis juliflora bark. Carbohydr Polym 92(2):1928-1933.

410 https://doi.org/10.1016/j.carbpol.2012.11.064.

411 Sathishkumar TP, Navaneethakrishnan P, Shankar S, Rajasekar R, Rajini N (2013) Characterization of 412 natural fiber and composites - A review. J Reinf Plast Compos 32(19):1457-1476. 413 https://doi.org/10.1177/0731684413495322.

414 Segal L, Creely J, Martin AEJ, Conrad C (1959) An Empirical Method for Estimating the Degree of 415 Crystallinity of Native Cellulose Using the X-Ray Diffractometer. Text Res J 29(10):786-794. 416 https://doi.org/10.1177/004051755902901003.

417 Seki Y, Sarikanat M, Sever K, Durmuşkahya C (2013) Extraction and properties of Ferula communis 418 (chakshir) fibers as novel reinforcement for composites materials. Compos Part B Eng 44(1):517-523. 419 https://doi.org/10.1016/j.compositesb.2012.03.013.

420 Seki Y, Seki Y, Sarikanat M, Sever K, Durmuşkahya C, Bozacı E (2014) Evaluation of linden fibre as a 421 potential reinforcement material for polymer composites. $\mathrm{J}$ Ind Text 45(6):1221-1238. 422 https://doi.org/10.1177/1528083714557055.

423 Seki Y, Sever K, Erden S, Sarikanat M, Neser G, Ozes C (2012) Characterization of Luffa cylindrica 424 fibers and the effect of water aging on the mechanical properties of its composite with polyester. J Appl 425 Polym Sci 123(4):2330-2337. https://doi.org/10.1002/app.34744.

426 Senthamaraikannan P, Kathiresan M (2018) Characterization of raw and alkali treated new natural 427 cellulosic fiber from Coccinia grandis.L. Carbohydr Polym 186:332-343. 428 https://doi.org/10.1016/j.carbpol.2018.01.072.

429 Sgriccia N, Hawley MC, Misra M (2008) Characterization of natural fiber surfaces and natural fiber 430 composites. Compos Part A Appl Sci Manuf 39(10):1632-1637. 
431 https://doi.org/10.1016/j.compositesa.2008.07.007.

432 Shanmugasundaram N, Rajendran I, Ramkumar T (2018) Characterization of untreated and alkali treated

433 new cellulosic fiber from an Areca palm leaf stalk as potential reinforcement in polymer composites.

434 Carbohydr Polym 195:566-575. https://doi.org/10.1016/j.carbpol.2018.04.127.

435 Silva FdA, Chawla N, Filho RDdT (2008) Tensile behavior of high performance natural (sisal) fibers.

436 Compos Sci Technol 68(15-16):3438-3443. https://doi.org/10.1016/j.compscitech.2008.10.001.

437 Vinod A, Vijay R, Singaravelu DL, Sanjay MR, Siengchin S, Moure MM (2019) Characterization of 438 untreated and alkali treated natural fibers extracted from the stem of Catharanthus roseus. Mater Res 439 Express 6(8):085406. https://doi.org/10.1088/2053-1591/ab22d9.

440 Zampieri A, Sieber H, Selvam T, Mabande GTP, Schwieger W, Scheffler F, Scheffler M, Greil P (2005) 441 Biomorphic Cellular SiSiC/Zeolite Ceramic Composites: From Rattan Palm to Bioinspired Structured 442 Monoliths for Catalysis and Sorption. Adv Mater 17(3):344-349. 443 https://doi.org/10.1002/adma.200400672. 


\section{Figures}

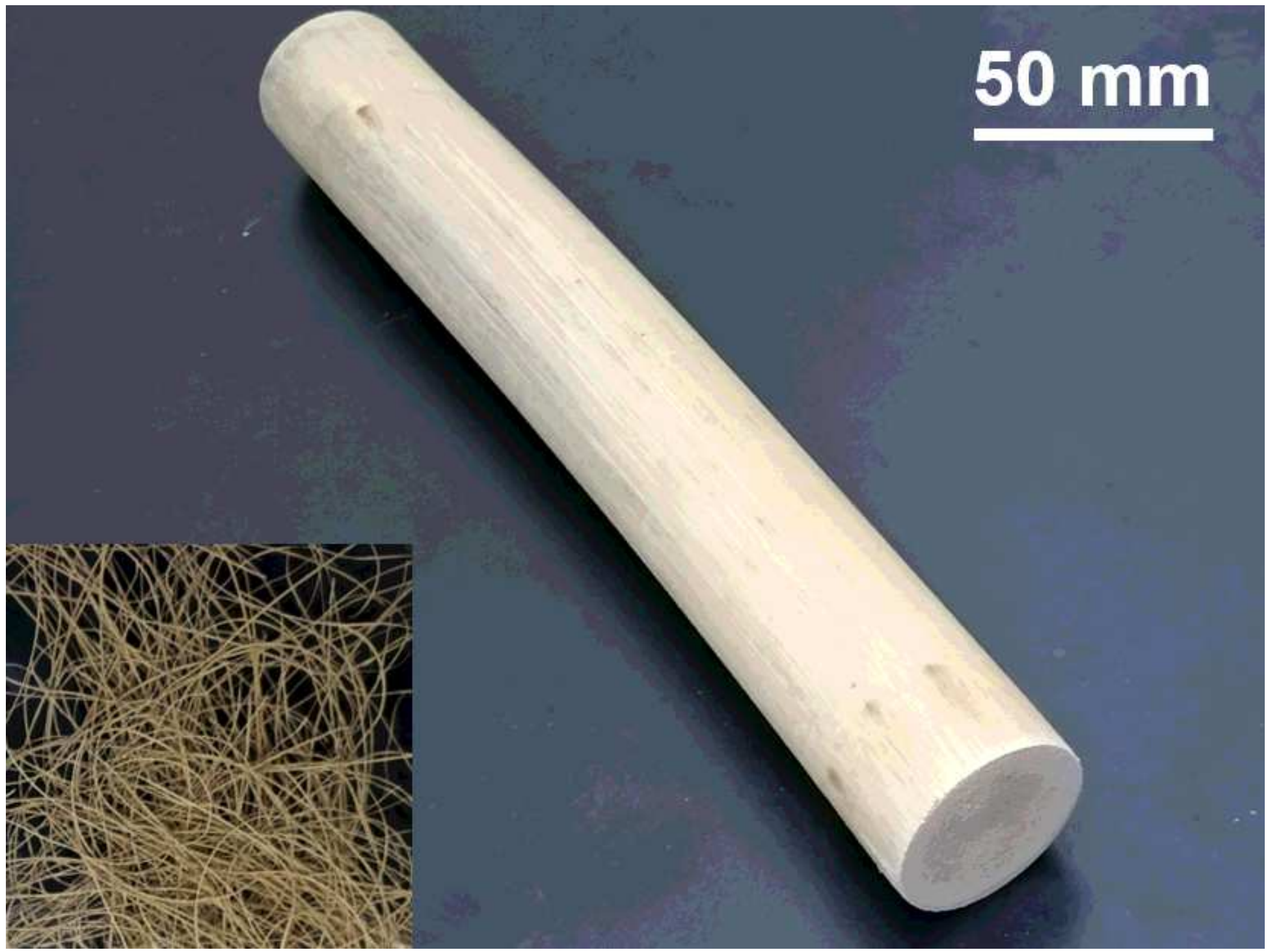

Figure 1

Stem of manau rattan with its extracted fiber 


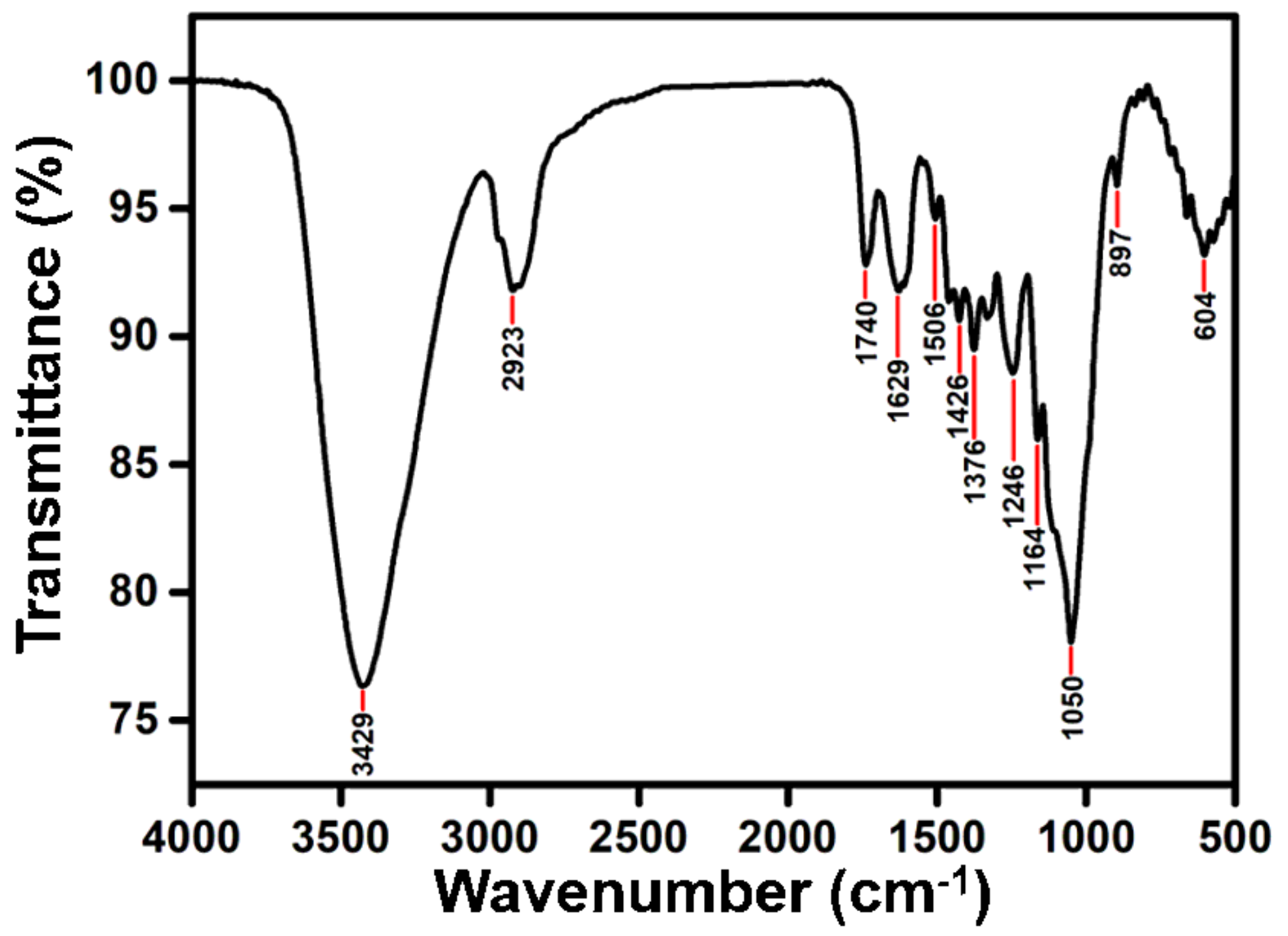

Figure 2

FTIR spectra of manau rattan fibers 

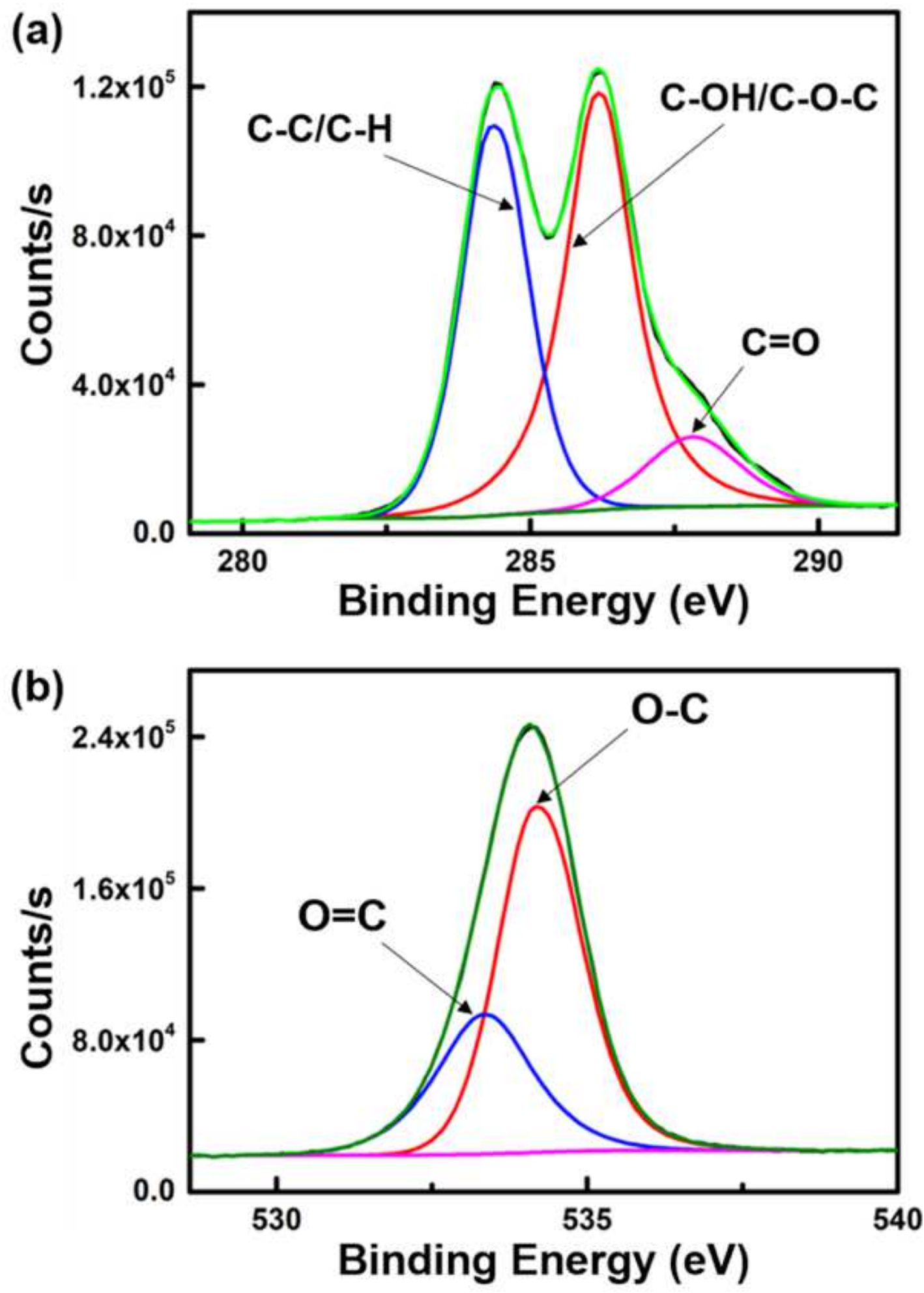

Figure 3

High resolution XPS spectra showing the deconvoluted C1s (a) and 01s (b) envelope 


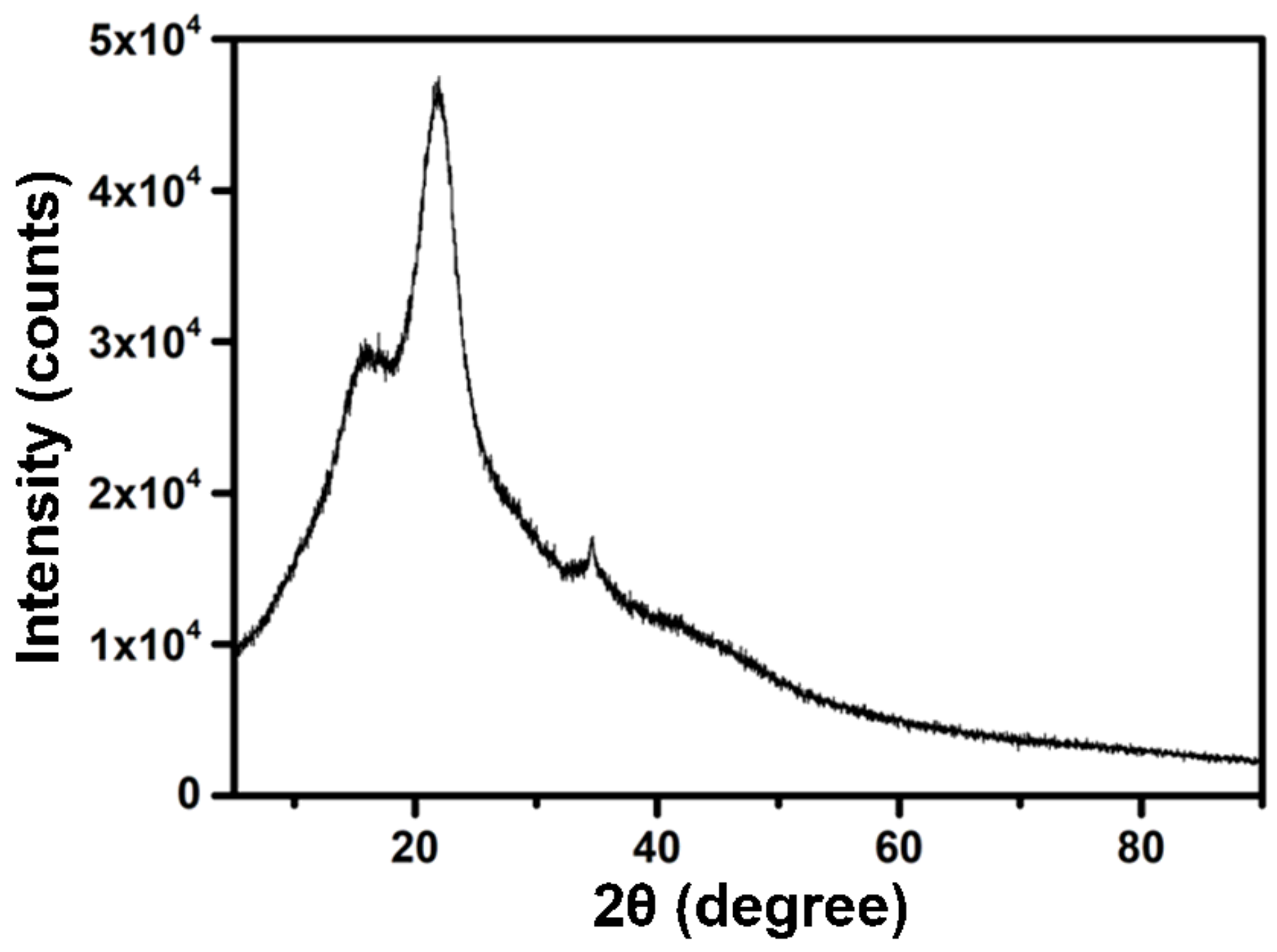

Figure 4

XRD graph of manau rattan fibers
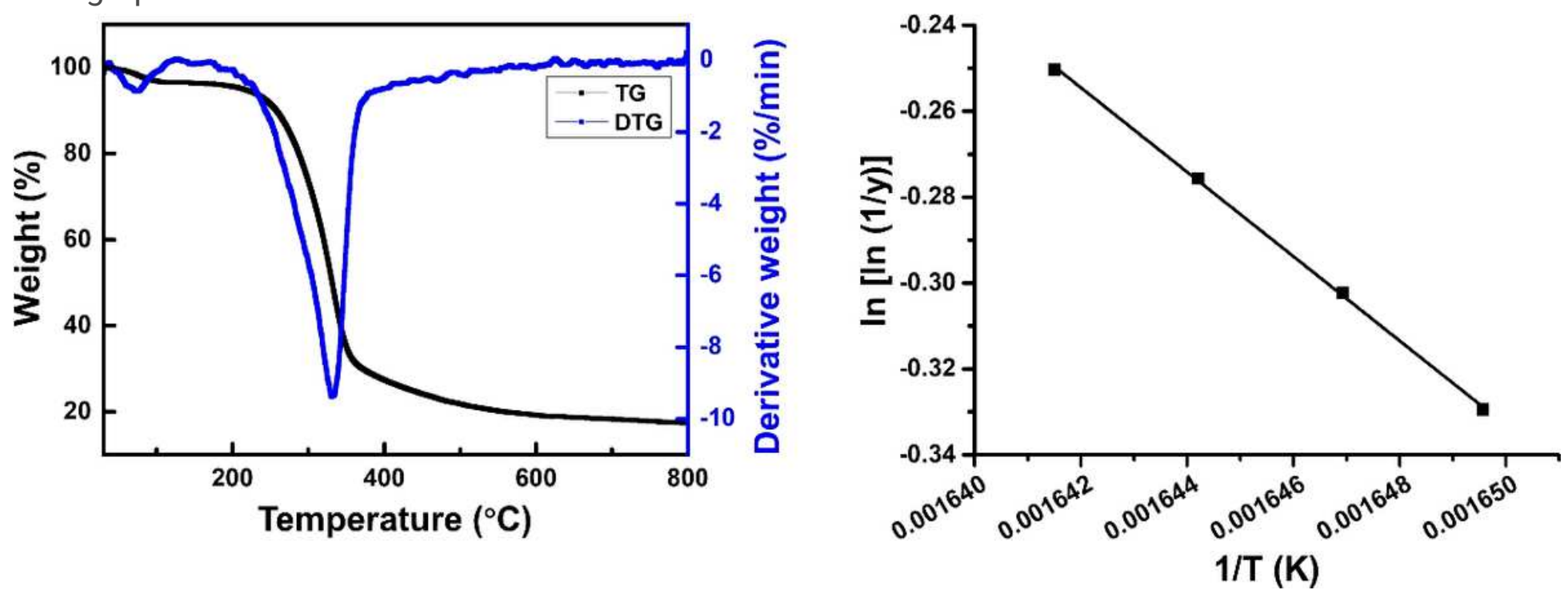

Figure 5 
TGA/DTG curves of manau rattan fibers (a) and Broido's plot of manau rattan fibers (b)
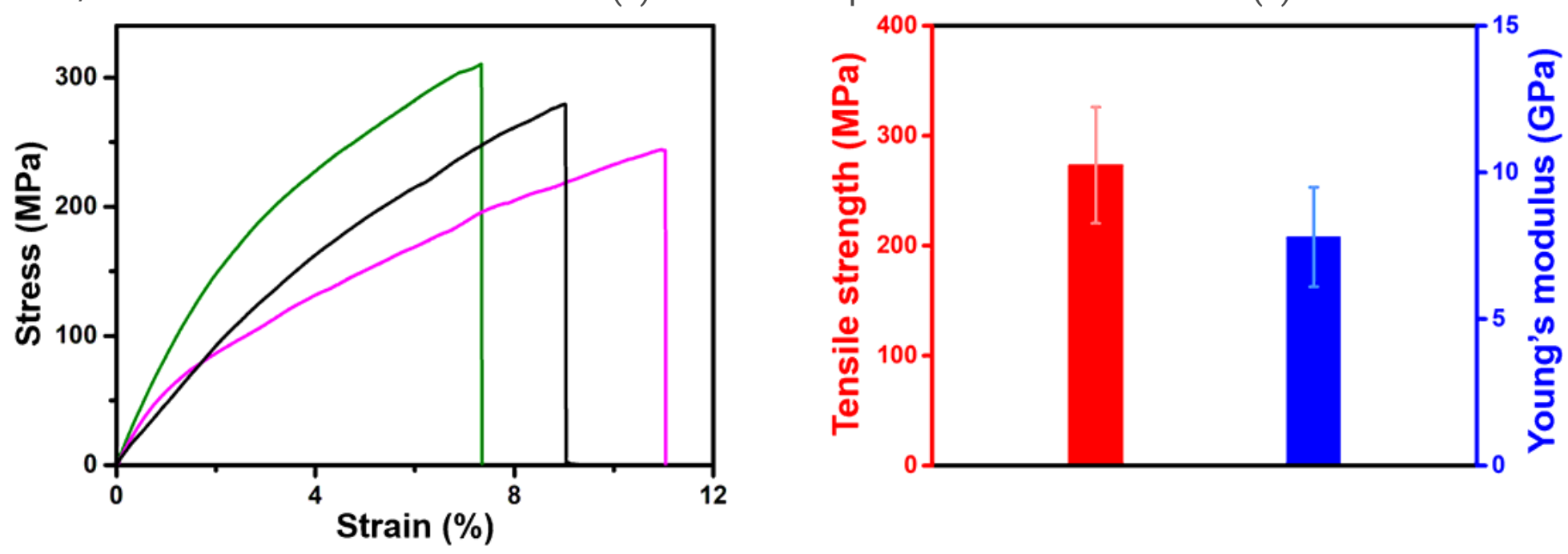

Figure 6

(a) Tensile stress-strain curve of manau rattan fiber and (b) its corresponding mechanical properties
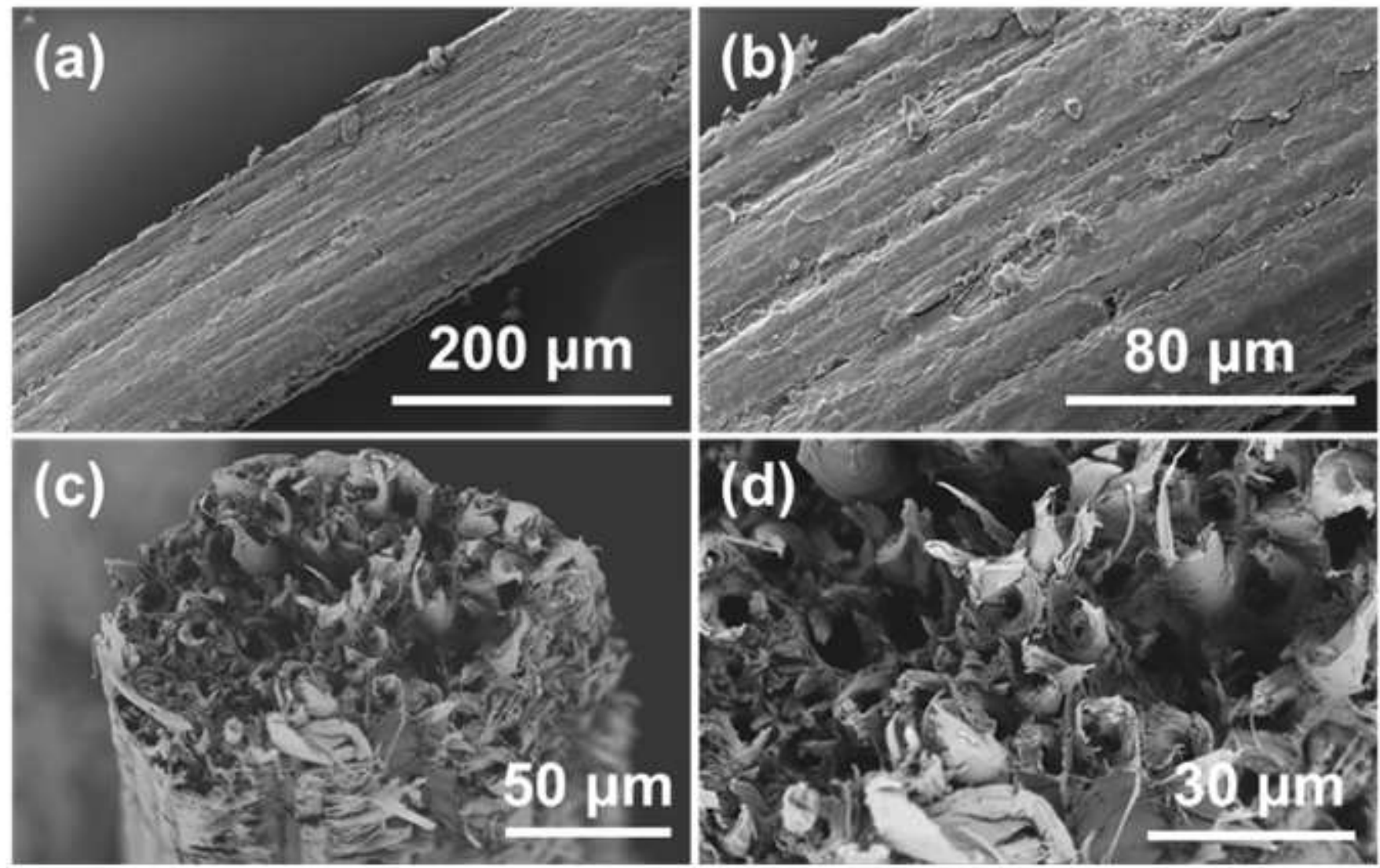

Figure 7

SEM micrographs of manau rattan fiber 